\title{
Melagenine modulates proliferation and differentiation of melanoblasts
}

\author{
DEKUANG ZHAO $^{1}$, YONGWEI LI ${ }^{1}$, PING WANG ${ }^{1}$, MIAONI ZHOU ${ }^{1}$, \\ CUIPING GUAN $^{1}$, XIAODONG WEI ${ }^{1}$, YINSHENG WAN ${ }^{2}$ and AIE XU ${ }^{1}$ \\ ${ }^{1}$ Department of Dermatology, the Third People's Hospital of Hangzhou, Hangzhou 310009, \\ P.R. China; ${ }^{2}$ Department of Biology, Providence College, Providence, RI 02918, USA
}

Received February 28, 2008; Accepted April 29, 2008

DOI: 10.3892/ijmm_00000008

\begin{abstract}
Melagenine, extracted from human placenta, has been shown to be effective in treating patients with vitiligo, yet the mechanisms of melagenine in inducing the repigmentation of vitiligo patients have not been fully investigated. Recent studies have suggested that melagenine stimulates melanocyte proliferation and melanogenesis. In this study, we utilized the NCCmelb4M5 melanoblast cell line to investigate the effects of melagenine on proliferation and differentiation of immature melanocytes or melanoblasts. NCCmelb4M5 cells were treated with different concentrations of melagenine (50-400 $\mu \mathrm{g} / \mathrm{ml})$, and MTT assay was performed to evaluate the effects of melagenine on proliferation of melanoblasts. RT-PCR and Western blotting were used to determine the expression of c-KIT and tyrosinase (TYR). Our results show that melagenine stimulates proliferation of NCCmelb4M5 cells in a dose-dependent manner with an optimal concentration of $100 \mu \mathrm{g} / \mathrm{ml}$. Multipolar and highly branched dendritic network, as well as cluster-like growing cell assembly were visible in melagenine-treated NCCmelb4M5 cells. Melagenine induced expression of c-KIT, TYR and MITF. Our results provide insights into the molecular mechanism of the beneficial effect of melagenine in the treatment of vitiligo.
\end{abstract}

\section{Introduction}

Vitiligo is an acquired pigmentary disorder characterized by depigmentation of skin and hair. Approximately $0-5 \%$ of the

Correspondence to: Dr Aie Xu, Department of Dermatology, the Third People's Hospital of Hangzhou, Hangzhou 310009, P.R. China E-mail: xuaiehz@sina.com

Dr Yinsheng Wan, Department of Biology, Providence College, RI 02918, USA

E-mail: yswan@providence.edu

Key words: melagenine, melanocytes, melanoblasts, proliferation, differentiation world's population is affected by this disease (1). Due to the poor understanding of the mechanism by which melanocytes (MCs) disappear from involved skin, treatment of vitiligo has generally been unsatisfactory. Traditional therapies that induce varying degrees of repigmentation in vitiligo patients include topical corticosteroids $(2,3)$, phototherapy (4), photochemotherapy (4), and helium-neon laser treatment (5).

It has been reported that MCs can be recruited from the outer root sheath of the hair follicle to repigment the vitiliginous skin through various forms of therapy $(6,7)$. Recovery of vitiligo was also initiated by proliferation and differentiation of the immature melanocytes (melanocyte precursors or melanoblasts), followed by their upward migration to the nearby epidermis to differentiate into MCs and form perifollicular pigment islands (4).

Melanocyte precursor, NCCmeb4M5, has recently been established (8), and was derived from NCCmelb4 cells. These cells were positive for melanocyte markers such as tyrosinaserelated protein 1 (TRP-1) and DOPAchrome tautomerase, but were negative for tyrosinase (TYR) and KIT. These characteristics made this cell line an ideal model to study the effects of many factors related to melanocyte development.

Recently, it was demonstrated that 12-O-tetradecanoyl phorbol 13-acetate (TPA) and cholera toxin (CT) induced KIT expression in NCCmelb4M5 cells which have the potential to differentiate into KIT-positive melanocyte precursors, and this may be useful in studying the mechanisms of development and differentiation of melanocytes in mouse neural crest cells (8).

Melagenine, an extract from human placenta, was first used for the treatment of vitiligo in 1991 (9). We previously reported that melagenine had therapeutic efficacy for child vitiligo patients by inducing repigmentation (10). Other studies have suggested that melagenine is an extremely rich reservoir of bioactive molecules, since some typical human placental extracts contain keratinocyte growth factor (11) or stimulators of endothelial cell growth (12).

It has been well documented that in the human placenta there are bioactive peptides such as endothelin-1 (ET-1) (13), adrenocorticotropic hormone (ACTH) (14) and sphingolipids (15), well-known modulators of different cellular responses. Our previous studies demonstrated that melagenine stimulates MC proliferation and melanin synthesis (10). Other researchers reported that human placental lipid induced melanogenesis in melanoma cells by increasing the expression of tyrosinase 
and its related proteins (16). Recent studies have suggested that human placental protein stimulates melanin synthesis by enhancing tyrosinase gene expression (17).

All the studies that employed melagenine focused on its biofunctions on MCs. In the present study, we used melanocyte precursors, NCCmelb4M5 cells, and studied the effects of melagenine on their proliferation and differentiation.

\section{Materials and methods}

Preparation of melagenine. Melaganine was prepared according to the method described previously (10), and the protocol was approved for use in our hospital by local authorities. Briefly, the total constituents of hydroalcoholic placental extracts were treated with ethanol and filtered on a sephadex column. The resulting colorless and lucent liquid examined negative of hepatitis virus, syphilis, leptospira, and human immunodeficiency virus (HIV), was used in this experiment.

Cell culture. The cell line NCCmelb4M5, is a melanocyte precursor derived from NCCmelb4 cells and was kindly provided by Professor Mizoguchi (St Marianna University School of Medicine, Japan). Cells were grown in a humidified atmosphere of $5 \% \mathrm{CO}_{2}$ and $95 \%$ air at $37^{\circ} \mathrm{C}$ in EMEM supplemented with 5\% FBS. Culture medium was changed every 3 days, and cells were subcultured when they became confluent for experiments.

MTT assay. NCCmelb4M5 cells $\left(1 \times 10^{5}\right)$ were seeded in a 96-well tissue culture plate. One day after seeding, cells were treated with melagenine at various concentrations $(0,50,100$, $200,400 \mu \mathrm{g} / \mathrm{ml})$. After $72 \mathrm{~h}$ of incubation, proliferation rate of NCCmelb4M5 cells was measured with MTT proliferation assay kit (ATCC, USA) according to the manufacturer's instructions.

RNA isolation and semi-quantitative RT-PCR. NCCmelb4M5 cells $\left(1 \times 10^{6}\right)$ were seeded onto a 6 -well cell culture plate and incubated for $24 \mathrm{~h}$. The cells were then treated with melagenine at a concentration of $100 \mu \mathrm{g} / \mathrm{ml}$. After $72 \mathrm{~h}$ of incubation, total RNA was extracted from melagenine-treated NCCmelb4M5 cells by TRIzol Reagent (Bio Basic Inc., Canada) and reverse-transcribed using a Reverse Transcription System Kit (MIB Fermentas, Vilnius, Lithuania) following the manufacturer's instructions. The cDNA as readout of mRNA was amplified by PCR using specific primers for c-KIT, TYR, MITF, and B-actin. Primers for c-KIT were, 5'-CGA CTG CCC GTG AAG TGG A-3' (sense) and 5'-GCC AGA AGG ACG GGG TCG G-3' (anti-sense). Primers for TYR were, 5'-TTC AAA GGG GTG GAT GAC-3' (sense) and 5'-GAC ACA TAG TAA TGC ATC-3' (anti-sense). Primers for MITF were, 5'-AGT CAC TAC CAG GTG CAG AC-3' (sense) and 5'-CTT GCT TCA GAC TCT GTG GG-3' (anti-sense). Primers for $\beta$-actin were, $5^{\prime}$-AGT GTG ACG TTG ACA TCC GT-3' (sense) and 5'-GCA GCT CAG TAA CAG TCC GC-3' (anti-sense). Cycling conditions were $30 \mathrm{sec}$ for denaturation at $94^{\circ} \mathrm{C}, 30 \mathrm{sec}$ of annealing at $66^{\circ} \mathrm{C}$ for c-KIT, $55^{\circ} \mathrm{C}$ for TYR and $\mathrm{B}$-actin, $60^{\circ} \mathrm{C}$ for MITF, and 1 min of extension at $72^{\circ} \mathrm{C}$ during 30 cycles for c-kit and TYR, 34 cycles for MITF and 25 cycles for $\beta$-actin. PCR products were visualized by electrophoresis in a $2 \%$ agarose gel containing $0.5 \mu \mathrm{g} / \mathrm{ml}$ ethidium bromide.

Western blot analysis. To detect expression of c-KIT and TYR at protein level, $2 \times 10^{6}$ NCCmelb4M5 cells were seeded onto a 6-well culture plate and incubated for $24 \mathrm{~h}$. Cells were then treated with melagenine at a concentration of $100 \mu \mathrm{g} / \mathrm{ml}$. After $72 \mathrm{~h}$ of incubation, cells were harvested and total proteins were extracted. For Western blot analysis, $40 \mu \mathrm{g}$ of extracted total cellular proteins were subjected to $10 \%$ SDSPAGE. Subsequently, they were electroblotted onto a nitrocellulose membrane for $1 \mathrm{~h}$ using a Mini Trans-Blot Transfer Cell (Bio-Rad, USA) at $90 \mathrm{~V}$. After blocking and washing, the nitrocellulose membrane was incubated with anti-c-KIT, anti-TYR monoclonal antibodies (1:1000 dilution, Santa Cruz, USA), followed by incubation with a 1:1000 dilution of horseradish peroxidase-labeled secondary antibody (Santa Cruz). The results were visualized by enhanced chemiluminescent method and analyzed by a digital imaging system.

Statistical analysis. The results were expressed as mean \pm SD. The Student's t-test was used for statistical evaluation between control and experimental groups in the study. The difference was considered statistically significant at P-value $<0.05$.

\section{Results}

Effect of melagenine on the proliferation of NCCmelb4M5 cells. We studied whether melagenine affects proliferation of NCCmelb4M5 cells. Cells were treated with various concentrations of melagenine, and MTT assay was performed to measure the proliferation rate of those cells. Our results show that melagenine induced proliferation of NCCmelb4M5 cells in a dose-dependent manner with an optimal concentration of $100 \mu \mathrm{g} / \mathrm{ml}$ (Table I).

Effect of melagenine on differentiation of NCCmelb4M5 cells. To further investigate whether melagenine induces NCCmelb4M5 cell differentiation, we treated the cells with $100 \mu \mathrm{g} / \mathrm{ml}$ of melagenine and cell morphology was observed under a microscope. We found that after treatment with melagenine, a remarkable phenotype change occurred in NCCmelb4M5 cells. As shown in Fig. 1, multipolar and highly branched dendritic network, as well as cluster-like growing cell assembly were visible in melagenine-treated NCCmelb4M5 cells. These data indicate that melagenine effectively induced the phenotype changes. As NCCmelb4M5 cells are immature melanocytes and were originally negative for melanocyte markers such as c-KIT and TYR, we consider that the growth promotion elicited by melagenine might be associated with their differentiation.

Induction of c-KIT and TYR by treatment with melagenine. We then examined the effects of melagenine on the expression of c-KIT and TYR. After $72 \mathrm{~h}$ of treatment with melagenine, semi-quantitative RT-PCR and Western blot analysis were carried out to measure the expression of c-KIT and TYR. Our results demonstrate that melagenine treatment induced c-KIT and TYR expression at both mRNA and protein levels in 
Table I. Effect of melagenine on the proliferation of NCCmelb4M5 cells.

\begin{tabular}{|c|c|c|c|c|}
\hline \multirow{2}{*}{$\begin{array}{l}\text { Groups } \\
\text { Control }\end{array}$} & \multicolumn{3}{|c|}{ OD (570 nm) } & \multirow{2}{*}{$\frac{\text { Average OD }(570 \mathrm{~nm})}{0.231 \pm 0.185}$} \\
\hline & 0.221 & 0.219 & 0.252 & \\
\hline Melagenine $(50 \mu \mathrm{g} / \mathrm{ml})$ & 0.413 & 0.452 & 0.383 & $0.416 \pm 0.346^{\mathrm{a}}$ \\
\hline Melagenine $(100 \mu \mathrm{g} / \mathrm{ml})$ & 0.856 & 0.756 & 0.814 & $0.809 \pm 0.050^{\mathrm{a}}$ \\
\hline Melagenine $(200 \mu \mathrm{g} / \mathrm{ml})$ & 0.766 & 0.634 & 0.726 & $0.709 \pm 0.068^{\mathrm{a}}$ \\
\hline Melagenine $(400 \mu \mathrm{g} / \mathrm{ml})$ & 0.710 & 0.843 & 0.719 & $0.757 \pm 0.074^{\mathrm{a}}$ \\
\hline
\end{tabular}

Cells were treated with melagenine at various concentrations; MTT assay was carried out after $72 \mathrm{~h}$ of incubation. Data are shown as the mean $\pm \mathrm{SD}$. Similar results were obtained in three independent experiments. ${ }^{\mathrm{a}} \mathrm{P}<0.05$.

A
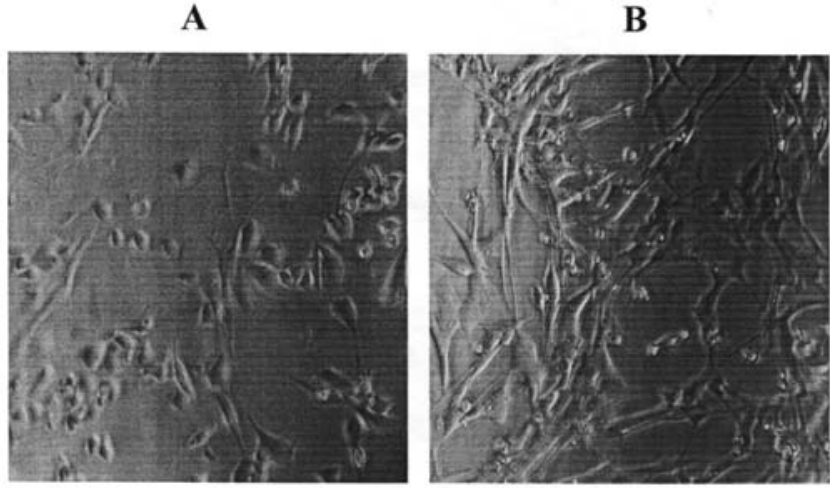

Figure 1. Morphologic changes after melagenine treatment. Phase-contrast photomicrographs of NCCmelb4M5 cells without (A) and with (B) melagenine treatment $(100 \mu \mathrm{g} / \mathrm{ml})$. The cells changed from polygonal in shape to bipolar or highly branched dendritic.

\section{A}

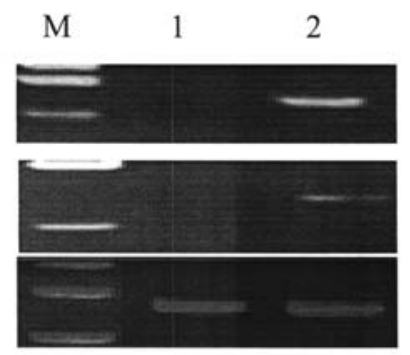

B

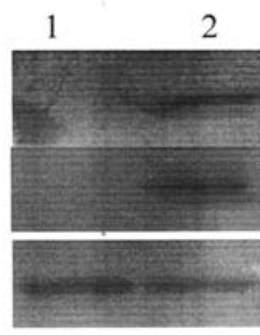

Figure 2. Effects of melagenine on TYR and c-KIT expression in NCCmelb4M5 cells. NCCmelb4M5 cells treated without or with melagenine $(100 \mu \mathrm{g} / \mathrm{ml})$ were collected and subjected to semi-quantitative RT-PCR (A) or Western blot analysis (B) as described in Materials and methods. One representative experiment of three is shown. M, marker; 1 , melagenine $(0 \mu \mathrm{g} / \mathrm{ml}) ; 2$, melagenine $(100 \mu \mathrm{g} / \mathrm{ml})$.

NCCmelb4M5 cells (Fig. 2). These results suggest that melagenine stimulated differentiation of immature melanocyte precursors.

Induction of MITF by treatment with melagenine. To further investigate the molecular basis of melanocyte precursor differentiation induced by melagenine, mRNA expression of MITF was tested. NCCmelb4M5 cells were incubated with

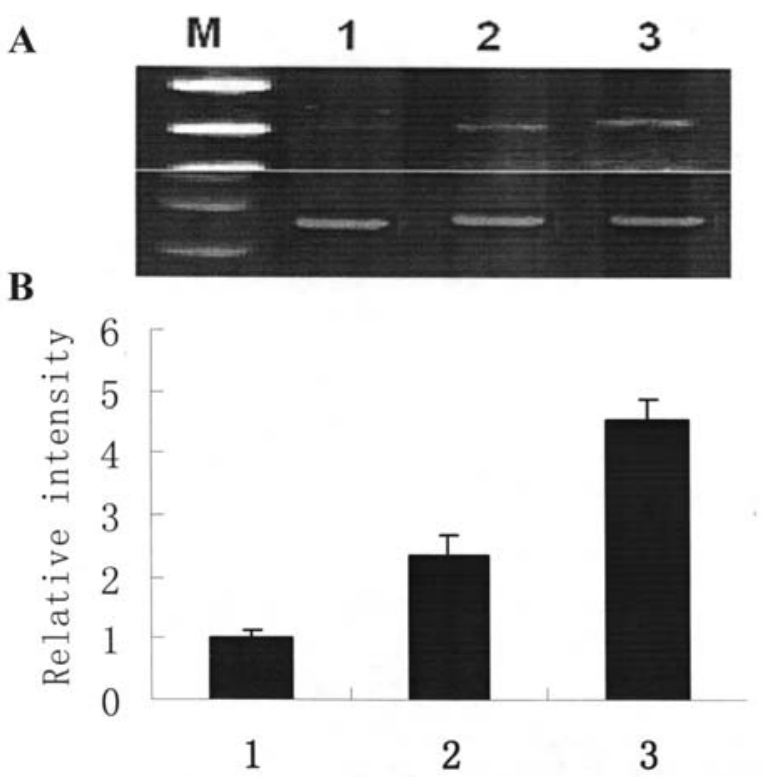

Figure 3. Increased expression of MITF by melagenine treatment. NCCmelb4M5 cells were treated with melagenine at various concentrations $(0,50,100 \mu \mathrm{g} / \mathrm{ml})$ for $72 \mathrm{~h}$ and then were collected and subjected to extraction of total cellular mRNA. After reverse transcription, cDNA was amplified by semi-quantitative RT-PCR using specific primers described in Materials and methods. The data shown are a representative result from separate experiments $(\mathrm{A})$ and the densitometric analyses (mean $\pm \mathrm{SD}$ ) were obtained from three independent experiments. M, marker; 1 , melagenine $(0 \mu \mathrm{g} / \mathrm{ml}) ; 2$, melagenine $(50 \mu \mathrm{g} / \mathrm{ml}) ; 3$, melagenine $(100 \mu \mathrm{g} / \mathrm{ml})$.

$(50,100 \mu \mathrm{g} / \mathrm{ml})$ or without melagenine for $72 \mathrm{~h}$, and then total RNA was extracted and analyzed by semi-quantitative RTPCR. As shown in Fig. 3, a marked induction of MITF mRNA was demonstrated following treatment with melagenine. These data suggest that this transcription factor may be the key modulator of melagenine-induced cell differentiation in NCCmelb4M5 cells.

\section{Discussion}

It is well documented that recovery of vitiligo is initiated by proliferation, migration and melanogenesis of melanocytes as well as the migration and differentiation of melanocyte precursors. Treatment of vitiligo with topical melagenine has been proven effective in a series of pre-clinical studies $(3,10)$, However, the underlying mechanisms of repigmentation induced by melagenine have not been thoroughly clarified. 
Previously we reported that the direct effects of melagenine on melanocytes may contribute to its therapeutic effect (10). It has also been reported that melagenine treatment induced changes in melanocyte growth and pigment-inducing activities in the skin of C57BL/6J mice (18), yet the effects of melagenine on melanocyte precursors have not been extensively studied. Therefore, in this study, we employed melanocyte precursor NCCmelb4M5 and investigated the effects of melagenine on its proliferation and differentiation.

In this study, we demonstrated that melagenine, which is a component of many bioactive molecules, promoted the growth of NCCmelb4M5 cells. The growth promotion was accompanied by increased expression of tyrosinase and c-KIT and alteration in cell shape from polygonal to bipolar or dendritic. In NCCmelb4m5 cell cultures, melagenine treatment also induced MITF expression. Collectively, our data suggest that melagenine directly stimulates proliferation and differentiation of immature melanocyte precursors.

Reverse transcription-PCR and Western blot analysis used in this study reveal that melagenine treatment induced c-KIT and TYR at both mRNA and protein levels in NCCmelb4M5 cells. This finding suggests that melagenine acts to promote the expression of c-KIT and TYR in immature melanocyte precursors and may also play an important role in modulating melanocyte development in vivo.

To the best of our knowledge, this is the first study to report the effect of melagenine on c-KIT and TYR expression. Previous in vivo studies have suggested the importance of transient c-KIT expression in melanoblast migration into the developing murine hair follicle (19). Part of our study demonstrated that melagenine enhanced migration of NCCmelb4M5 cells (data not shown). Whether the melagenine-induced expression of c-KIT in NCCmelb4M5 cells mediates cell migration needs to be further investigated.

Accumulating data indicate that MITF plays a pivotal role in regulating melanocyte development, survival, and differentiation $(20,21)$. MITF is the human homolog of the mouse microphthalmia ( $\mathrm{mi}$ ) gene product, which was identified as a novel transcription factor of the basic helixloop-helix (bHLH) leucine zipper protein family. Studies on the cell-specific expression of tyrosinase have shown that the M-box in the upstream promoter region of the tyrosinase gene is required for its efficient expression in melanocytes. This motif contains a canonical CANNTC motif that is recognized and bound by MITF.

Since melagenine induced tyrosinase expression, it would be interesting to see whether melagenine alters MITF expression in NCCmelb4M5 cells. In this study, RT-PCR analysis revealed that MITF mRNA expression is markedly increased by melagenine treatment, suggesting that MITF may be the key factor in melagenine-induced melanocyte differentiation. This is the first study showing the induction of MITF by treatment with melagenine.

Human placenta is enriched with numerous bioactive components, among which are melanocyte activity modulators including pro-opiomelanocortin peptides and corticotrophin releasing factor and other growth factors such as ET-1, bFGF (22-25). ET-1 is a versatile peptide, originally identified as a vasoactive component, demonstrating significant mitogenic, dendritic inducing and melanogenic activities in melanocytes
(26). bFGF stimulates proliferation of murine melanoblasts, as well as human melanocytes (27).

Furthermore, the sphingolipids have a highly bioactive back bone (sphingoid bases and ceramides) and have been implicated in the regulation of cell growth and differentiation (28), with their metabolites also being implicated in controlling a delicate rheostatic switch to balance cell growth promotion and inhibition signals (29). Recently, one novel sphingolipid or its metabolites, namely sphingosylphosphorylcholine (SPC) and sphingosine-1-phosphate (S1P) was reported to be mitogenic in human melanocyte cells (30). Most recent studies reported that sphingolipids upregulate tyrosinase gene expression at transcription level (31). Our previous studies demonstrated the presence of sphingolipids and several growth factors such as ET-1 and bFGF in melagenine. Thus, the promotion of proliferation and differentiation of NCCmelb4M5 cells by melagenine is very likely due to the presence of the sphingolipids and some growth factors which have been proven to be effective stimulators of melanocyte development.

In conclusion, we showed in vitro evidence demonstrating direct effects of melagenine on proliferation and differentiation of melanocyte precursor NCCmelb4M5 cells. We also provided data showing that melagenine induces c-KIT, TYR and MITF expression in NCCmelb4M5 cells. Our findings provide insights into the molecular mechanism of melagenine in the treatment of vitiligo.

\section{Acknowledgments}

This study was supported in part by a grant from the Science Research Foundation of the Ministry of Health of the People's Republic of China (WKJ2005-2-050) a grant from the Natural Science Foundation of Zhejiang Province (Y204468), and a grant from NIH (P20 RR016457 from the INBRE Program of the National Center for Research Resources).

\section{References}

1. Kovacs SO: Vitiligo. J Am Acad Dermatol 38: 647-668, 1998.

2. Njoo MD, Spuls PI, Bos JD, Westerhof W and Bossuyt PM: Nonsurgical repigmentation therapies in vitiligo. Meta-analysis of the literature. Arch Dermatol 134: 1532-1540, 1998.

3. Mandel AS, Haberman HF, Pawlowski D and Goldstein E: Non PUVA nonsurgical therapies for vitiligo. Clin Dermatol 15: 907-919, 1997.

4. Fitzpatrick TB: Mechanisms of phototherapy of vitiligo. Arch Dermatol 133: 1591-1592, 1997.

5. Yu HS, Wu CS, Yu CL, Kao YH and Chiou MH: Helium-neon laser irradiation stimulates migration and proliferation in melanocytes and induces repigmentation in segmental-type vitiligo. J Invest Dermatol 120: 56-64, 2003.

6. Forschner T, Buchholtz S and Stockfleth E: Current state of vitiligo therapy - evidence-based analysis of the literature. J Dtsch Dermatol Ges 5: 467-475, 2007.

7. Cui J, Shen LY and Wang GC: Role of hair follicles in the repigmentation of vitiligo. J Invest Dermatol 97: 410-416, 1991.

8. Kawa Y, Soma Y, Nakamura M, Ito M, Kawakami T, Baba T, Sibahara K, Ohsumi K, Ooka S, Watabe H, Ono H, Hosaka E, Kimura S, Kushimoto T and Mizoguchi M: Establishment of a kit-negative cell line of melanocyte precursors from mouse neural crest cells. Pigment Cell Res 18: 188-195, 2005.

9. Suite M and Quamina DB: Treatment of vitiligo with topical melagenine - a human placental extract. J Am Acad Dermatol 24: 1018-1019, 1991

10. Xu AE and Wei XD: Topical melagenine for repigmentation in twenty-two child patients with vitiligo on the scalp. Chin Med J 117: 199-201, 2004 
11. Chiu ML and O'Keefe EJ: Placental keratinocyte growth factor: partial purification and comparison with epidermal growth factor. Arch Biochem Biophys 269: 75-85, 1989.

12. Presta M, Mignatti P, Mullins DE and Moscatelli DA: Human placental tissue stimulates bovine capillary endothelial cell growth, migration and protease production. Biosci Rep 5: 783-790, 1985.

13. Wilkes BM, Susin M and Mento PF: Localization of endothelin1-like immunoreactivity in human placenta. J Histochem Cytochem 41: 535-541, 1993.

14. Shibasaki T, Odagiri E, Shizume K and Ling N: Corticotropinreleasing factor-like activity in human placental extracts. J Clin Endocrinol Metab 55: 384-386, 1982.

15. Pal P, Roy R, Datta PK, Dutta AK, Biswas B and Bhadra R: Hydroalcoholic human placental extract: skin pigmenting activity and gross chemical composition. Int J Dermatol 34: 61-66, 1995.

16. Mallick S, Singh SK, Sarkar C, Saha B and Bhadra R: Human placental lipid induces melanogenesis by increasing the expression of tyrosinase and its related proteins in vitro. Pigment Cell Res 18: 25-33, 2005.

17. Sarkar C, Singh SK, Mandal SK, Saha B, Bera R, Ratha J, Datta PK and Bhadra R: Human placental protein/peptides stimulate melanin synthesis by enhancing tyrosinase gene expression. Mol Cell Biochem 285: 133-142, 2006.

18. Pal P, Mallick S, Mandal SK, Das M, Dutta AK, Datta PK, Bera R and Bhadra R: A human placental extract: in vivo and in vitro assessments of its melanocyte growth and pigment-inducing activities. Int J Dermatol 41: 760-767, 2002.

19. Peters EM, Tobin DJ, Botchkareva N, Maurer M and Paus R: Migration of melanoblasts into the developing murine hair follicle is accompanied by transient c-Kit expression. J Histochem Cytochem 50: 751-766, 2002.

20. Levy C, Khaled M and Fisher DE: MITF: master regulator of melanocyte development and melanoma oncogene. Trends Mol Med 12: 406-414, 2006.

21. Murisier F, Guichard S and Beermann F: The tyrosinase enhancer is activated by Sox 10 and Mitf in mouse melanocytes. Pigment Cell Res 20: 173-184, 2007.
22. Grigorakis SI, Anastasiou E, Dai K, Souvatzoglou A and Alevizaki M: Three mRNA transcripts of the proopiomelanocortin gene in human placenta at term. Eur J Endocrinol 142: 533-536, 2000.

23. Challis JR, Matthews SG, Van Meir C and Ramirez MM: Current topic: the placental corticotrophin-releasing hormoneadrenocorticotrophin axis. Placenta 16: 481-502, 1995.

24. Fant ME and Nanu L: Human placental endothelin: expression of endothelin-1 mRNA by human placental fibroblasts in culture. Mol Cell Endocrinol 109: 119-123, 1995.

25. Shams $M$ and Ahmed A: Localization of mRNA for basic fibroblast growth factor in human placenta. Growth Factors 11: 105-111, 1994.

26. Monji $\mathrm{A}$, Inoue $\mathrm{H}$, Oshima $\mathrm{H}$, Aihara $\mathrm{M}$, Tomioka $\mathrm{M}$ and Kumagai N: Tyrosinase induction and inactivation in normal cultured human melanocytes by endothelin-1. Int J Tissue React 27: 41-49, 2005

27. Hirobe T, Osawa M and Nishikawa S: Hepatocyte growth factor controls the proliferation of cultured epidermal melanoblasts and melanocytes from newborn mice. Pigment Cell Res 17: 51-61, 2004.

28. Spiegel S and Milstien S: Sphingolipid metabolites: members of a new class of lipid second messengers. J Membr Biol 146: 225-237, 1995.

29. Mandala SM, Thornton R, Tu Z, Kurtz MB, Nickels J, Broach J, Menzeleev R and Spiegel S: Sphingoid base 1-phosphate phosphatase: a key regulator of sphingolipid metabolism and stress response. Proc Natl Acad Sci USA 95: 150-155, 1998.

30. Higuchi K, Kawashima M, Ichikawa Y and Imokawa G: Sphingosylphosphorylcholine is a melanogenic stimulator for human melanocytes. Pigment Cell Res 16: 670-678, 2003.

31. Saha B, Singh SK, Sarkar C, Mallick S, Bera R and Bhadra R: Transcriptional activation of tyrosinase gene by human placental sphingolipid. Glycoconj J 23: 259-268, 2006. 